European journal of American studies

Special Issue: Women in the USA

\title{
"First Lady But Second Fiddle" or the rise and rejection of the political couple in the White House: 1933-today.
}

Pierre-Marie Loizeau

\section{(2) OpenEdition Journals}

Electronic version

URL: https://journals.openedition.org/ejas/10525

DOI: $10.4000 /$ ejas. 10525

ISSN: 1991-9336

Publisher

European Association for American Studies

Electronic reference

Pierre-Marie Loizeau, "'First Lady But Second Fiddle" or the rise and rejection of the political couple in the White House: 1933-today.", European journal of American studies [Online], 10-1 | 2015, document 1.5, Online since 26 March 2015, connection on 08 July 2021. URL: http://journals.openedition.org/ejas/ 10525 ; DOl: https://doi.org/10.4000/ejas. 10525

This text was automatically generated on 8 July 2021.

Creative Commons License 


\title{
"First Lady But Second Fiddle" or the rise and rejection of the political couple in the White House: 1933- today.
}

\author{
Pierre-Marie Loizeau
}

1 One of the striking points of the presidential function lies in its being exclusively male. In the country of democracy and freedom par excellence, half of the population, as it were, has been excluded from electoral rolls. In reality, female representation has been one of the great weaknesses of the American government, not to mention the whole body politic in the history of the Republic Despite undeniable progress, especially in the last forty years, female leaders remain a minority in the country. The three women who have held the post of state secretaries (Madeleine Albright, Condoleezza Rice, and Hillary Clinton) in the last three administrations and the former House Speaker (Nancy Pelosi) remain exceptions to the rule. Most important posts, at federal, state and local levels still keep a strong male tonality.

2 This conspicuous underrepresentation of women in politics leads us to examine the role(s) of those who, though devoid of any official function, yet move in the spheres of executive power every day. In many respects, the First Ladies of the nation, as they are commonly known, can be counted among the most prominent American public figures. Both mirrors and models of American womanhood, they have contributed to the elevation of women's status in society. They have now acquired such celebrity that people can more readily identify with their First Lady than they can with the Vice President or Cabinet secretaries. The president's wife repeatedly tops the Gallup Organization's annual poll of the country's "Most Admired Women." In 1995, one year after her death, one of the most famous First Ladies of the twentieth century, Jackie Kennedy, still received $1 \%$ of the vote for the most admired woman ... living today! Yet this popularity tells only part of the story. 
3 The First Ladyship has long been regarded as "the unknown institution" of the White House. 'Until the 1980s, it was mostly ignored by scholars, historians and overlooked by political scientists. However, this is changing. Today, the office has become a powerful component of the administration with its own staff and budgetary resources and the First Lady is now viewed as a central figure of the presidency by the public, media and the political establishment. The former traditional role of presidential wives has made way for what is viewed by many as a real partnership function with the president.

\section{1 - The initiators: the Roosevelts}

4 When "Franklin and Eleanor" occupied the White House some eighty years ago, they initiated a new concept in presidential politics, that of the "First Couple". Before them, despite a limited definition of the president's role and the total absence of definition of the First Lady's role, clear-cut cultural codes guided the White House couple's course of action. No interaction seemed to affect each other's position. The president led the nation according to constitution and his wife complied with the rules of tradition by filling her public role as the White House hostess and her private responsibilities of wife, mother and homemaker. Having no constitutional position and not even having a title until the early twentieth century when Charles Nirdlinger's play First Lady of the Land encountered popular success, she remained away from the spotlight.ii As such, the "presidential couple" had never been a matter of concern or controversy. Some First Ladies had been more supportive of their husbands than others, some had proved more influential than others, some had been more controversial than others but they had never really defined the presidents, and the public had never identified the President and his wife as an essential "First Couple" institutional entity.

5 The Roosevelts in the White House somewhat changed the rules and challenged the deep-seated conventions of marriage, government and society. FDR's famous "fireside chats" in particular allowed him to go directly to the people and create an intimate and direct communication between himself and American citizens. As Ronald Reagan indicated in his autobiography: "During the Fireside Chats, his strong, gentle, confident voice resonated across the nation with an eloquence that brought comfort and resilience to a nation caught up in a storm and reassured us that we could lick any problem." ${ }^{\text {iii }}$ By introducing the federal government into the American home, he reformed both governmental and parental functions. Historian Gil Troy claims that the state was "domesticated" as "it usurped parental functions relating to economic welfare and education", thus preventing the family from its institutional role and indirectly reinforcing its emotional, and consequently less stable, character. More significantly, the presidency was "domesticated." The unprecedented proximity between the president and his citizens magnified the so-called American values and made the president a moral leader and national figurehead. He really personified the nation.

6 Eleanor, on her side, also contributed to personifying the presidency. More than any of her predecessors, she acted as the president's emissary, his "eyes and ears." As he preferred not to be seen in a wheelchair, FDR often sent ER to inspect hospitals, prisons, asylums, and other government institutions and programs. She became an 
expert at probing deeply into the conditions she observed and in providing her husband with detailed reports. She travelled from the mines of West Virginia to American overseas military bases to extend the president's perceptual reach to all his constituents. She personalized the president's concern for the fighting Americans in World War II and learned the hard facts about domestic working conditions in West Virginia. As a non-stop do-gooder and because of her strong character and incessant activism, she also used the information gathered on these tours to lobby for specific social policy and educate the public through her writings (in particular her daily newspaper column My Day), speeches, lectures and radio broadcasts. Unlike other women married to powerful men who appeared as accessories to power, Eleanor complemented her husband's image. Because of her symbolic power, she transformed the office of First lady into what Nancy Reagan would later call "a white glove pulpit" or even, according to Susan Breitzer, "a bully pulpit." iv In 1939, she publicly resigned from the "Daughters of the American Revolution" after this organization refused Constitution Hall to black singer Marian Anderson. In response, Eleanor lobbied Secretary of Interior Harold Ickes for Ms Anderson to give a concert on the steps of the Lincoln Memorial with the Mall of Washington as her auditorium, an event which drew a crowd of 75,000.

7 The Roosevelts were perceived as the dynamic couple of the White House for about two decades (1930s and 1940s) fighting against poverty and injustice on all fronts. However, admiration for the teamwork was not unanimous and angry Southerners in particular spurned the couple's complicitstrategy of power. Handbills circulated showing a wily Franklin telling his wife about a winning plan of action: "You kiss the Negroes and I'll kiss the Jews and we'll stay in the White House as long as we choose." Eleanor's fame and influence raised a growing anger among political opponents, critics and also ordinary Americans as she supposedly violated the genteel boundaries of the First Ladyship. She was derided as "Madam President," "Lenin in skirts," "Stalin in petticoats," "Empress Eleanor," "the most dangerous individual in the United States today," etc. vi She was asked to join the WW2 effort by "keeping quiet." In one famous editorial, the New York Times warned her about her outspokenness and her desire to be a national sounding board about the Depression:

"It is not indelicate or impolite to express the hope that she will refrain from such utterances in the future. The very best helpers of a president are those who do all they can for him, but keep still about it."vii

8 As criticism of her influence, or so-called influence mounted, her standing with the president also suffered and FDR turned to his daughter, Anna, to serve as his political mouthpiece. Eleanor then confessed she "lived those years very impersonally. It was almost as though I had erected someone a little outside of myself who was the president's wife. I was lost somewhere deep down inside myself." viii Despite her independence and her potential as an activist and an inspiration, Eleanor was faced with the limits of her First Lady role. While she had been given national prominence in helping her husband define the times, lead the nation to its economic recovery and establish a political identity in the postwar America, she also had to endure the society's fear of, or discomfort with, powerful women in general and presidential spouses in particular.

9 Her experience recurrently reveals two conflicting aspects of her role. She always demonstrated her strong need for freedom of action but she was also an advocate of the First Lady as a supportive and helpful spouse. She believed in Victorian values but 
repeatedly violated these rules. "Even if a woman has the most definite ideas," she confessed, "she must never try to persuade her husband to do anything he does not consider right..." ix As if complying with the New York Times, she said that "a political wife may have her own opinions but she must keep them to herself." $\mathrm{x}$ Yet, as historian Blanche Wiesen Cook demonstrates, "in the Roosevelt household, there were always two politicians." ${ }^{\times i}$ The truth is the power game offered her many opportunities but also left her fettered to her husband's desires or vagaries. As she conceded to the Ladies Home Journal, "very little that I have done in life seems to have been done as a matter of choice." ${ }^{\mathrm{xi}}$

10The Roosevelt presidency is interesting as it initiated the myth of the policymaking First Lady. The rise of the mass media and the culture of celebrity it produced, the women's fascination for a powerful role model in Washington, in a Depression and WW2 era of historic magnitude, along with the pioneering role Eleanor Roosevelt established in the White House, led to the belief that policy-making was integral to a First Lady's function. However, as Troy wrote, "presidential couples are supposed to work together on joint-image-making, not power-sharing." ${ }_{\text {xii }}$ Confusion between fame and power, visibility and influence, ambition and tradition constrained the First Lady role. Eleanor Roosevelt learned it the hard way.

\section{2 - Partnership v. co-presidency}

11The Roosevelts marked a turning-point in the history of presidents and First Ladies. Despite the limits of her role, Eleanor extended the presidential spouse's scope of action in unprecedented ways and the couple's joint leadership inspired many of their successors. With varying degrees, each presidency since the Roosevelts has indeed seen the First Lady's involvement in the political fray. Presidents' wives are now recognized by the press and the public as important players in the nation's political drama.

12 Modern First Ladies do act as political and presidential partners. Most of them have functioned as the president's confidante or adviser. However there are differing degrees of involvement. First lady scholar Robert Watson established a typology of partnerships, some being considered full political partners (like Eleanor Roosevelt, Rosalynn Carter, Hillary Clinton), others partial partners (Mamie Eisenhower, Jackie Kennedy, Betty Ford), others behind-the-scenes partners (Bess Truman, Nancy Reagan, Barbara Bush). The full partner is of course very active in politics, wielding influence both publicly and privately and is a top presidential adviser. The partial partner serves as a presidential adviser and supports her husband's political activities. She may assist the president with his speeches and demonstrate some interest in the issues and have been a supporter of her husband's career and campaigns before joining the White House but not as a major force. By definition, the behind-the scenes partner never takes part publicly in political or presidential affairs. She may be a powerful and influential force but always in private. ${ }^{\text {iv }}$ Bess Truman, for instance always presented herself as "just the wife of the president and the mother of his daughter." But, as Gil Troy observes, the 1948 presidential campaign somewhat disclosed her ambivalent style: 
"Two Bess Trumans were on view. At times she was the small-town matron, hushing her husband when he called her "the Boss". She played den mother to the President and his entourage. (...)

At other times, Bess was the savvy behind-the-scenes pol who projected a homey image. As usual, she was Harry's toughest critic; she edited his speeches, shaped his appeals ..."xv

13Harry Truman himself once conceded that his wife "was a full partner in all my transactions - politically and otherwise." She had her say on the most sensitive files, including "whether to fight in Korea, whether to use the atom bomb, [and] whether to initiate the Marshall plan to rebuild a shattered Europe." ${ }_{x v i}$

14 Watson's categorization is certainly interesting but reflects only part of the truth as First Ladies may change their partnership style during their husband's mandate. Bill Clinton's second race to the White House offers an interesting illustration of this phenomenon. In 1992, the major campaign slogans had been "Buy one, Get one free!", "Two for the price of one!" Hillary echoed her husband's words with: "If you elect Bill, you also get me!" Four years later, the method changed radically. The campaign downplayed the First lady's role. Gone were the pronouns 'we' in the president's speeches and references to "Bill and Hillary" simply disappeared from the White House rhetoric. There were no more hints that Hillary might serve in the Cabinet. She was forced to remain silent among major issues and her visibility was under the meticulous control of the president's ruthlessly efficient campaign machine. This was the price to pay to keep Bill Clinton in the White House another four years.

150ne of the main difficulties the First Lady has to face when she enters the White House rests in the absence of clear definition of her function. There is only an empirical knowledge of the role which every new First Lady has to reinvent or reinterpret every four years according to historical circumstances, political culture as well as to her own persona and ambition. To better apprehend the function and avoid too much improvisation, Hillary clinton had decided to read forty-three biographies of her predecessors. For others, on the contrary, the situation was so dreadful that they refused to prepare it. They saw public functions and proximity to power as major obstacles to well-being and family life. This was the case of so-called "invisible First Ladies" of the nineteenth century like Margaret Taylor, Anna Harrison, Jane Pierce or Eliza McCardle Johnson. For modern First Ladies, the challenge has been to find their bearings and understand the enormous potentialities of the position without breaking rules or overstepping bounds. Living in the corridors of power, temptation can be strong to impose one's political ideas, method or style. Beyond certain limits, though, a First Lady may constitute a risk for the success of a presidency.

16Among the major issues raised by the influence of First Ladies is the existence of a possible "co-presidency," a phrase that was coined during the Roosevelt administration and which reappeared after the feminist movement of the 1960 s and 1970s. The fear is that the nation might be led by a presidential team, not just an elected individual. After their accession to the White House in 1992, the "Clinton Couple" acted and were perceived as a political entity, a symbiosis that their opponents derisively labeled "Billary." The media noted that the presidential mansion was visited by as many FOHs (Friends Of Hillary) as FOBs (Friends Of Bill). The dual image was prevalent, focusing on either "the president and his wife" or "the first lady and her husband". But more than anything else, the real impact of this duality was a reinforced visibility of the president's spouse and consequently an imposed legitimacy of her role within the 
administration. Mrs. Clinton symbolically moved her office to the West Wing of the White House, "with all the men", in the power place. Soon, though, all the media and the political world bristled with antagonisms and denounced Mrs. Clinton's undue and unconstitutional seizure of power. She was called "Dragon Lady," "Mrs. President," "copresident," etc. D. Herbert Lipson wrote ironically:

"With Bill Clinton, we truly elected the First Couple, ... The Clintons apparently define their marriage in terms so broadly political that they may have exchanged position papers instead of marriage vows." "xvii

17The point is the media directed similar criticisms against previous First Ladies, regardless of the presidencies' political orientation, Democrat or Republican. Rosalynn Carter was first attacked for assisting her husband, Jimmy, and for sitting in on Cabinet meetings with him. Then, as Jimmy was plagued by a national crisis of confidence, Rosalynn's public prominence climaxed. The press first wondered if she was "really running the country." Then they blamed her for acting as co-president and impacting on U. S. policy. Nancy Reagan was also attacked for being power hungry and especially for initiating the firing of President Ronald Reagan's former Secretary of the Treasury and the White House Chief of Staff, Donald Regan.

18These examples also support the idea that the co-presidency, as the union of two powers, does not necessarily result in a superior power. It may even lead to a weakening of the presidential institution. Essayist Katha Politt notes that the presidential couple interacts like communicating vessels: "In the zero-sum game of traditional marriage, a strong wife means a weak husband."xviii About Nancy Reagan's role in Donald Regan's eviction, William Safire of the New York Times wrote: "At a time when he most needs to appear strong, President Reagan is being weakened and made to appear wimpish and helpless by the political interference of his wife." "xix His comment echoed Richard Nixon's words about the Clinton couple: "If the wife comes through as being too strong and too intelligent, it makes the husband look like a wimp." ${ }_{\mathrm{xx}}$

19Interestingly, the more power Presidential wives seem to wield, the lower their popularity. Only when they appear more traditional do they receive high approval ratings, a phenomenon that is confirmed by the Gallup pollsters: "Once again, the Most Admired Woman list is largely populated by the unpowerful or uncontroversial." xxi

\section{3 - Abolish her?}

20This paper also suggests that despite their unequal involvement, the experience First Ladies have acquired through the years has set precedence and enhanced women's credibility on the political stage. They have campaigned for their husbands, supported their careers, offered political advice, edited political speeches, embraced and promoted policies and served as their husbands' most trusted and closest political ally. Their greater influence has accompanied their greater visibility. An uninvolved First Lady would be a great anachronism now.

21However, the role of presidents' wives, as shown by such feminists as Germaine Greer, seems to be one of great ambiguity and consequently raises a lot of frustration. Does the First Lady's partnership status constitute an elevation or perpetuate an institutional inferiority, of women? Does the First Lady-style fusion of "the personal and the political," a concept put forward by feminists, represent an expansion of women's political power? Although their proximity to power has inevitably given First 
Ladies political influence, it must be recognized that their mere "residential" or territorial vantage position, acquired through the legal tie of marriage, does not reflect a major mark of political power for women. It is true that if a wife, be it Hillary Clinton or even Michelle Obama today, can make a big difference on how voters perceive her husband, and therefore enhance his electoral chances, her own political authority is clearly non-existent. It depends entirely on her husband's ambitions. Katha Pollitt defined the problem in reference to Hillary Clinton:

"Hillary Clinton may be a new-style politician's wife, but she represents an old mode of women's political power: access to powerful men, rather than power itself." $\times x$ ii

220ne scene of the TV series Scandal symptomatically reflects the ambiguities of the First Lady's role and the tension arising when she deliberately oversteps her so-called boundaries. In a well staged presentation before the TV cameras, the president and his pregnant wife are informed of their future baby's sex. She seizes this opportunity to disclose the US intention to launch a military intervention in Sudan, a public announcement that ruins the government's effort to keep the operation secret ... and raises the president's ire! The words he uses in response reveal more than anger. They speak volumes on his perception of the First Lady's role:

Reporter: "Now I know you are even more excited about what's in this envelope than I am, so I won't keep torturing you two anymore."

President Fitzgerald Grant: "Just tell us already."

Reporter: "All right. Here we go everyone... America's baby is ...: a boy!"

President: "A baby boy!"

First Lady Melody "Mellie" Grant: "Oh, Kimberly, I am so glad. I am just so glad, in light of this wonderful news, with a baby boy about to be born into our family, that my amazing husband and his administration believe in doing whatever is necessary in East Sudan to protect those mothers and their beautiful children from the truly horrific genocide that is happening...

I'm so sorry. It's just my m...my hormones.

Reporter: "Have you come up with any names yet?"

A few minutes later, behind closed doors...

First Lady: "Are we not going to discuss... Just oh, Fitz! I understand that you're upset, but there is no reason for you ..."

President: "You ambushed me on live TV, you tried to force my hand, and you used our unborn child to do it."

First Lady: "I simply did what I always do, which is help you get the result that you need . . . They're saying this might be the highest-rated news broadcast on any network in years so I think it worked. And I struck just the tone you need with the public both hands on my belly as I shared my concern ..."

President: "No one elected you! You're not the president! You don't weigh in on foreign policy. Your opinion doesn't matter! You are the First Lady. Your job is to plant gardens and decorate rooms and let them blog about your clothes.

You're ornamental, not functional.

So don't come into the Oval [Office] and try to use your brain, because no one cares."

First Lady: "You always did know just the right way to hurt me."

President: "Mellie..."

First Lady: "I gave up my law career so you could run for office. I didn't have to do that."

President: "I know that. And I appreciate it. I do. (...) I apologize. Really. I'm sorry."

First Lady: "The baby's kicking. Do you want to feel?"

President: "Yeah."xxiii 
Obviously, the president's final act of contrition sounds little convincing and does not minimize the impact of his angry words just before. Beyond the scene's dramatic effect, fiction joins reality, or vice versa. A wife abandons her career to serve her husband's political purposes. He gets elected. Then her role is to "stand by her man" and play the trophy wife. "Ornamental, not functional." That is where the frustration lies for many women in their perception of the First Lady job which remains that of "First Lady but second fiddle."

240fficially, the First Lady is not even recognized or protected by the Constitution. Therefore, if she is perceived as too eager for power, then she maintains a state of confusion that some denounce as an attempt at usurping power. In fact, does she have any real power at all?

25 What a growing number of ambitious women in politics want is not an unofficial First Lady-like status any more but the red meat of real power. More radically, some feminists like Germaine Greer have proposed to simply "abolish her," on the grounds that there should be no such thing as "power through the wedding ring," an alliance which is anathema with the ideals of American democracy. The Clinton model gave her an opportunity to severely attack the First Lady function:

"The elevation of a democratically elected leader's unelected consort makes a mockery of the democratic process itself... In a democratic world, mere relationship to an elected officeholder should simply never be a route to power... It can no longer be acceptable that a person should achieve high visibility, influence and even a degree of executive power simply because she shares a bed ... with a head of state."xxiv

26...Yet can the First Lady be "abolished?" The suggestion sounds more provocative than realistic. There is a couple living in the White House and the influence wielded by a wife is inherent in marriage life. The institution of marriage is universal, for presidents just as for ordinary people. It is even difficult to imagine a bachelor president today, or a president going on an official trip abroad with a "First Girlfriend!" Greer's suggestion certainly reflects the individualistic culture of Americans but in the presidential context it represents a small segment of public opinion. For the public and the media, the First Lady really incarnates the presidential couple and more than ever is a popular figure in the United States. The political role of the presidential consort does not jeopardize the democratic process in any way. The political structures are strong enough to prevent or repress any threats of usurpation of power.

27To conclude, this paper has shown that the emergence of the presidential couple has been one of the most significant and controversial developments in America's postwar political history. It has been the creation of popular desire. In return, it is expected to project an ideal dimension and serve as a moral guide and an inspiration. It is perceived as a very strong national symbol, a template of American values, and holds a powerful place in the American dream, or dreams, which have reflected or shaped the national identity. In this respect, Americans need traditional icons in the White House as a pledge of stability. In a 1992 New York Times article, Gary Wills recalled that for almost two centuries, the president had been cast in the WASP mold as:

“-a white, male, married Protestant, middle to upper class, with children and dogs.

He comes straight out of Central Casting. The exceptions only underline the rule. One bachelor (Buchanan). One Catholic - and not till 1960. No divorced man till 1980. No woman, Jew or African American." $x x v$ 
28Today's presidential reality contradicts this statement and it seems the country is ready for a woman in the Oval Office. However, even in case of such historic role reversal, the First Couple will abide by the same rules. The president will have to preside. The First Gentleman (whatever his name) will have no choice but to play as "second fiddle." Again, the key to success will be: joint image-making, not power sharing. ${ }^{\text {xvi }}$

\section{NOTES}

i. Robert P. Watson, The Presidents' Wives: Reassessing the Office of First Lady (Boulder, Co: Lynne Rienner Publishers, Inc., 2000), 19.

ii. The exact origin of the term "First Lady" still remains an enigma and opinions diverge among the various authors and historians who have investigated the question. It seems, however, that President Zachary Taylor's eulogy at Dolley Madison's funeral in 1849 marked what a number of scholars identify as the initial public use of the modern title: "She will never be forgotten, because she was truly our First Lady for a half-century." See Maureen H. Beasley, First Ladies and the Press - the Unfinished Partnership of the Media Age (Evanston, IL.: Northwestern University Press, 2005), 35. Yet the general public did not refer to the president's wife as the "First lady" until the second decade of the twentieth century.

iii. Ronald Reagan, An American Life (New York: Simon \& Schuster, 1990), 66.

iv. Susan Roth Breitzer, "Eleanor Roosevelt: An Unlikely Path to Political Activist." In Robert P. Watson \& Anthony Eksterowicz, eds. The Presidential Companion. Readings on the First Ladies (Columbia: University of South Carolina Press, 2003), 159. The phrase "bully pulpit" was first coined by Theodore Roosevelt to refer to the White House, a place of great influence from which he could advocate an agenda or lecture the nation on how government should regulate big business. The "white glove pulpit" refers to the feminine means of asserting power.

v. Doris Kearns Goodwin, No Ordinary Time - Franklin \& Eleanor Roosevelt: The Home Front in World War II (New York: Touchstone/Simon \& Schuster, 1994), 539.

vi. Alice Roosevelt Longworth's words. See the editorial column: “. . . Curiosity must be kept alive." The Free Lance-Star, 30 November, 1984, 16.

vii. The New York Times, 28 January 1933. Quoted byBetty Houchin Winfield, "The First Lady, Political Power, and the Media: Who Elected Her Anyway?," in Pippa Norris, dir., Women, Media and Politics (New York : Oxford University Press, 1997), 172.

viii. Gil Troy, Affairs of State (New York: Free Press, 1997), 10-11.

ix. Blanche Wiesen Cook, Eleanor Roosevelt. Vol. 1: 1884-1933 (New York: Penguin, 1992), 424.

x. Ibid., 426.

xi. Ibid.

xii. Ladies Home Journal (April 1945): 33.

xiii. Gil Troy, "Mr. and Mrs. President? The rise and fall of the co-presidency," The Social Science Journal 37 (Winter 2000): 592.

xiv. Watson, The Presidents' Wives, 140-141.

xv. Gil Troy, Affairs of State,43.

xvi. Karen O'Connor et al, "Wives in the White House: the Political Influence of First Ladies," Presidential Studies Quarterly (summer 1996): 836. 
xvii. D. Herbert Lipson, "Off the Cuff," Philadelphia Magazine, November 1993, 1.

xviii. Katha Pollitt. "Are we ready for a First Lady as first partner?" Glamour, September 1992, 329.

xix. William Safire, New York Times, 2 March, 1987, 17.

xx. Garry Wills, “A Doll's House?” The New York Times Book Review, 22 October, 1992, 10.

xxi. George Gallup, Jr., et al., The Gallup Poll - Public Opinion 1995 (Wilmington, DE: Scholarly Resources, Inc., 1996), 196.

xxii. Pollitt, Glamour, 332.

xxiii. Scandal, season 2, episode 1, "White Hats Off" (2012-2013). Created by Shonda Rhimes. Produced by ABC Studios. Distributed by Disney-ABC Domestic Television. 24'38" to 25'35".

xxiv. Germaine Greer, "Abolish her: The feminist case against First Ladies," The New Republic, 25 June, 1995, 23.

xxv. Wills, “A Doll's House," 6.

xxvi. Troy, Mr. and Mrs. President?: 592.

\section{ABSTRACTS}

The First Lady has emerged as an institution of great influence. Whether out in the open like Hillary Clinton or behind the scenes like Nancy Reagan, most First Ladies have served as their husbands' most trusted and closest political allies. Thus the modern era has seen the advent of the presidential couple, as symbolically epitomized in the 1990s' neologism "Billary." It seems, however, that the American public is not ready to accept power-sharing in the White House and that the First Lady, visible and influential though she might be, should not play the role of a copresident. A number of feminists simply propose to "abolish" her.

\section{INDEX}

Keywords: co-presidency, constitution, democracy, feminism, First Couple, First Lady, image, influence, media, partnership, policymaking, power, president, visibility, women

Mots-clés: Alice Roosevelt Longworth, Anna Harrison, Anna Roosevelt, Barbara Bush, Bess Truman, Betty Ford, Bill Clinton, Charles Nirdlinger, Condoleezza Rice, Dolley Madison, Donald Regan, Eleanor Roosevelt, Eliza McCardle Johnson, Franklin Delano Roosevelt, Germaine Greer, Harold Ickes, Harry Truman, Hillary Clinton, Jackie Kennedy, James Buchanan, Jane Pierce, Jimmy Carter, John Fitzgerald Kennedy, Madeleine Albright, Mamie Eisenhower, Margaret Taylor, Marian Anderson, Michelle Obama, Nancy Pelosi, Nancy Reagan, Richard Nixon, Ronald Reagan, Rosalynn Carter, Zachary Taylor

\section{AUTHOR}

\section{PIERRE-MARIE LOIZEAU}

8 Avenue Pasteur, 49100 Angers, France; pierre-marie.loizeau@univ-angers.fr; pm.loizeau@yahoo.fr 